\title{
Pengaruh Komunikasi Internal Terhadap Kinerja Karyawan
}

\author{
Kristina Munthe ${ }^{1 *}$ dan Ermina Tiorida ${ }^{2}$ \\ ${ }^{1}$ Jurusan Administrasi Niaga, Politeknik Negeri Bandung, Indonesia \\ 2 Jurusan Administrasi Niaga, Politeknik Negeri Bandung, Indonesia
}

\begin{abstract}
:
Organization consist of a number of people who works together or interact one another to achieve a goal. Internal communication is communication that occurs in organization or company, either horizontal or vertical. The purpose of this research is to examine the impact of internal communication (vertical and horizontal) to performance of employees. The questionnaire are distributed to 117 employees of PT Promedrahardjo Farmasi Industri. Data analysis technique that used are validity test, reliability test and simple linear regression with program SPSS 20.0 for Windows. The result conclude that to improve the performance, management need to provide more formal or non-formal forum for their employees to say their honest opinions and build up the intimacy between employees and management.
\end{abstract}

Keywords: communications, internal communications, performance employees

\begin{abstract}
Abstrak:
Organisasi terdiri dari sejumlah orang yang bekerja sama atau berinteraksi satu sama lain untuk mencapai suatu tujuan tertentu. Komunikasi internal diantara para anggota organisasi terjadi baik dalam hubungan timbal balik secara vertikal maupun secara horizontal. Penelitian ini bertujuan untuk mengetahui adanya pengaruh komunikasi internal (vertikal dan horizontal) terhadap kinerja karyawan. Data didapatkan dari studi pustaka dan sebaran kuesioner serta wawancara terhadap 117 karyawan di PT Promedrahardjo Farmasi Industri. Teknik analisis data yang digunakan adalah uji validitas, uji reliabilitas, analisis regresi linear sederhana dengan program SPSS 20.0 for Windows. Hasil penelitian menyimpulkan bahwa untuk meningkatkan kinerja, manajemen harus lebih banyak menyediakan waktu khusus bagi para pegawainya agar mereka bisa mengeluarkan pendapatnya dalam suatu forum formal maupun non-formal sehingga terjalin keakraban diantara para pegawai dan manajemen.
\end{abstract}

Kata Kunci: kinerja karyawan, komunikasi, komunikasi internal

\section{PENDAHULUAN}

\section{Komunikasi Internal}

Komunikasi internal didefinisikan oleh Lawrance D. Brennan dalam Effendy (2006:122) pertukaran gagasan diantara

*Email korespondensi:

Kristina Munthe

Kristina19041994@gmail.com para administrator dan karyawan dalam suatu perusahaan atau jawatan yang menyebabkan terwujudnya perusahaan atau jawatan tersebut lengkap dengan struktur yang khas (organisasi) dan pertukaran gagasan secara horizontal dan vertical didalam perusahaan atau jawatan yang menyebabkan pekerjaan berlangsung. Sedangkan menurut Yulianita, 
"komunikasi internal yaitu komunikasi yang terjadi di antara orang-orang yang berada dalam suatu perusahaan.

$$
\text { Menurut Effendy (2001:2), }
$$

komunikasi internal meliputi berbagai cara yang dapat diklarifikasi sebagai berikut, yakni: komunikasi personal (Personal communication). Komunikasi Personal adalah komunikasi dua orang dan dapat langsung dengan dua cara:

1. Komunikasi tatap muka (face to face communication) Komunikasi persona tatap muka berlangsung secara dialogis sambil saling menatap sehingga terjadi kontak pribadi (personal contact).

2. Komunikasi bermedia (mediated communication) Komunikasi persona bermedia dalah komunikasi dengan menggunakan alat, umpamanya talapon atau memorandum. Karena melalui alat, maka antara kedua orang tersebut tidak terjadi kontak pribadi.

Satu dari tujuan komunikasi internal adalah membantu orang untuk secara memadai melakukan pekerjaan mereka ( Smith, 2005; Mayer,2004 dalam Medina 2015). Temuan menunjukkan bahwa komunikasi internal adalah area besar penelitian yang berbeda antara organisasi dengan konten, struktur dan manajemen (Zondi, 2015).

\section{Komunikasi Vertikal}

Komunikasi vertikal bisa disebut juga komunikasi ke bawah dan komunikasi ke atas. Adapun pengertian dari komunikasi ke atas dan komunikasi ke bawah sebagai berikut.

1) Komunikasi ke bawah

Davis dalam (Pace dan Faules, 1998: 184) menyatakan komunikasi ke bawah dalam sebuah organisasi berarti bahwa informasi mengalir dari jabatan berotoritas tinggi kepada mereka yang berotoritas lebih rendah. Biasanya kita beranggapan bahwa informasi bergerak dari manajemen kepada para pegawai; namun, dalam organisasi kebanyakan hubungan ada pada kelompok manajemen. Ada lima jenis informasi yang biasa dikomunikasikan dari atasan kepada bawahan (Katz \& Kahn, 1966 dalam Pace dan Faules, 1998: 186): (1). Informasi mengenai bagaimana melakukan pekerjaan, (2). Informasi mengenai dasar pemikiran untuk melakukan pekerjaan, (3). Informasi mengenai kebijakan dan praktik-praktik organisasi, (4). Informasi mengenai kinerja pegawai, dan (5). Informasi untuk mngembangkan rasa memiliki tugas (sense of mission).

Para pegawai diseluruh tingkat organisasi merasa perlu diberi informasi. Manajemen puncak hidup dalam dunia informasi. Kualitas dan kuantitas informasi harus tinggi agar dapat membuat keputusan yang bermanfaat dan cermat. Manajemen puncak harus memiliki informasi dari semua unit dalam organisasi, dan harus memperoleh informasi untuk semua unit. Aliran informasi dari manajemen puncak yang turun ke tingkat operatif merupakan aktifitas yang berkesinambungan dan sulit. Pemilihan cara menyediakan informasi mencakup tidak hanya pengeluaran sumber daya langsung moneter tetapi juga sumber daya psikis dan emosional. Fungsi komunikasi dari atas kebawah adalah untuk : instruksi (perintah), briefing (pengarahan), melakukan penilaian, penanaman ideologi, pemberian penghargaan, melakukan teguran, pemberian insentif dan tunjangan.

2) Komunikasi ke atas

Komunikasi ke atas dalam sebuah organisasi berarti bahwa informasi mengalir dari tingkat yang lebih rendah (bawahan) ke tingkat yang lebih tinggi (penyelia). Semua pegawai dalam sebuah organisasi, kecuali mungkin mereka yang menduduki posisi puncak, mungkin berkomunikasi ke atas yaitu, setiap bawahan dapat mempunyai alasan yang baik atau 
meminta informasi dari atau memberi informasi kepada seseorang yang otoritasnya lebih tinggi dari pada dia. Suatu permohonan atau komentar yang diarahkan kepada individu yang otoritasnya lebih besar, lebih tinggi, atau lebih luas merupakan esensi komunikasi ke atas.

Komunikasi ke atas penting karena beberapa alasan. Kebanyakan analisis dan penelitian dalam komunikasi ke atas menyatakan bahwa penyelia dan manajer harus menerima informasi dari bawahan mereka yang:

a. Memberitahukan apa yang dilakukan bawahan - pekerjaan mereka, prestasi, kemajuan, dan rencana-rencana untuk waktu mendatang.

b. Menjelaskan persoalan-persoalan kerja yang belum dipecahkan bawahan yang mungkin memerlukan beberapa macam bantuan.

c. Memberikan saran atau gagasan untuk perbaikan dalam unit-unit mereka atau dalam organisasi sebagai suatu keseluruhan.

d. Mengungkapkan bagaimana pikiran dan perasaan bawahan tentang pekerjaan mereka, rekan kerja mereka dan organisasi.

\section{Komunikasi Horizontal}

Komunikasi horizontal terdiri dari penyampaian informasi diantara rekanrekan sejawat dalam unit kerja yang sama. Unit kerja meliputi individu-individu yang ditempatkan pada tingkat otoritas yang sama dalam organisasi dan mempunyai atasan yang sama. Jadi, di universitas, unit kerja dapat berubah sesuai jurusan. Jurusan komunikasi, jurusan perilaku organisasi, dan jurusan ilmu pengajaran semuanya meliputi dosen-dosen yang dipimpin oleh seorang ketua jurusan. Komunikasi diantara dosen-dosen dalam sebuah jurusan disebut komunikasi horizontal. Komunikasi dosen yang satu dengan dosen yang lainnya disebut komunikasi lintassaluran, yaitu informasi yang diberikan melewati batas-batas fungsional atas batasbatas unit kerja, dan diantara orang-orang yang satu sama lainnya tidak saling menjadi atasan dan bawahan. Tujuan komunikasi horizontal, penelitian dan pengalaman menyatakan bahwa komunikasi horizontal muncul paling sedikit karena enam alasan sebagai berikut:

a. Untuk mengkoordinasikan penugasan kerja.

b. Berbagi informasi mengenai rencana dan kegiatan.

c. Untuk memecahkan masalah.

d. Untuk memperoleh pemahaman bersama.

e. Untuk menumbuhkan dukungan antar persona.

Pace dan Faules (2010:185) mengungkapkan hambatan-hambatan pada komunikasi horizontal banyak persamaanya dengan hambatan yang mempengaruhi komunikasi ke atas dan komunikasi ke bawah. Ketidakpercayaan diantara rekan-rekan kerja, perhatian yang tinggi pada mobilitas ke atas, dan persaingan dalam sumber daya dapat mengganggu komunikasi pegawai yang sama tingkatnya dalam organisasi dengan sesamanya.

Faktor utama yang mempengaruhi efektivitas komunikasi internal adalah berbagi informasi, tidak menyeluruhnya informasi yang disampaikan, tidak menghargai komunikasi, waktu dan hirarki (Chmielecki, 2015).

\section{Kinerja Karyawan \\ Definisi Kinerja Karyawan}

Kinerja apabila dikaitkan dengan performance sebagai kata benda (noun), maka pengertian performance atau kinerja adalah hasil kerja yang dapat dicapai oleh seseorang atau kelompok orang dalam suatu perusahaan sesuai dengan wewenang dan tanggung jawab masing-masing dalam upaya pencapaian tujuan perusahaan 
secara ilegal, tidak melanggar hukum dan tidak bertentangan dengan moral dan etika (Rivai \& Basri, 2004; Riniwati 2011).

Menurut Sinambela, dkk (2012) dalam Riniwati, 2011 mengemukakan bahwa kinerja pegawai didefinisikan sebagai kemampuan pegawai dalam melakukan sesuatu keahlian tertentu. Kinerja pegawai sangatlah perlu, sebab dengan kinerja ini akan diketahui seberapa jauh kemampuan pegawai dalam melaksanakan tugas yang dibebankan kepadanya. Untuk itu diperlukan penentuan kriteria yang jelas dan terukur serta ditetapkan secara bersamasama yang dijadikan sebagai acuan. Menurut Riniwati (2011), kinerja adalah sejauh mana seseorang telah memainkan baginya dalam melaksanakan strategi organisasi, baik dalam mencapai sasaran khusus yang berhubungan dengan peran perorangan dan atau dengan memperlihatkan kompetensi yang dinyatakan relevan bagi organisasi. Kinerja adalah suatu konsep yang multi dimensional mencakup tiga aspek yaitu sikap (attitude), kemampuan (ability) dan prestasi (accomplishment). Berdasarkan uraian tersebut di atas dengan pencatatan hasil kerja (proses) yang dicapai oleh seseorang karyawan dalam melakukan suatu pekerjaan dapat dievaluasi tingkat kinerja pegawainya, maka kinerja karyawan harus dapat ditentukan dengan pencapaian target selama periode waktu yang dicapai organisasi.

$\begin{array}{ccc}\quad \text { Mutu } & \text { kerja karyawan } & \text { secara } \\ \text { langsung } & \text { mempengaruhi } & \text { kinerja }\end{array}$
perusahaan. Guna mendapatkan kontribusi karyawan yang optimal, manajemen harus memahami secara mendalam strategi untuk mengelola, mengukur dan meningkatkan kinerja, yang dimulai terlebih dahulu dengan menentukan tolak ukur kinerja. Ada beberapa sayarat tolak ukur kinerja yang baik, yaitu:

a. Tolak ukur yang baik, haruslah mampu dikukur dengan cara yang dapat dipercaya. b. Tolak ukur yang baik, harus mampu membedakan individu-individu sesuai dengan kinerja mereka.

c. Tolak ukur yang baik, harus sensitif terhadap masukan dan tindakantindakan dari pemegang jabatan.

d. Tolak ukur yang baik, harus dapat diterima oleh individu yang mengetahui kinerjanya sedang dinilai.

\section{Kriteria-Kriteria Kinerja}

Kriteria kinerja adalah dimensidimensi pengevaluasian kinerja seseorang pemegang jabatan, suatu tim, dan suatu unit kerja. Secara bersama-sama dimensi itu merupakan harapan kinerja yang berusaha dipenuhi individu dan tim guna mencapai strategi organisasi.

Menurut Schuler dan Jackson 2004 (dalam Riniwati 2011) bahwa ada 3 jenis dasar kriteria kinerja yaitu:

1. Kriteria berdasarkan sifat memusatkan diri pada karakteristik pribadi seseorang karyawan. Loyalitas, keandalan, kemampuan berkomunikasi, dan keterampilan memimpin merupakan sifat-sifat yang sering dinilai selama proses penilaian. Jenis kriteria ini memusatkan diri pada bagaimana seseorang, bukan apa yang dicapai atau tidak dicapai seseorang dalam pekerjaanya.

2. Kriteria berdasarkan perilaku terfokus pada bgaimana pekerjaan dilaksanakan. Kriteria semacam ini penting sekali bagi pekerjaan yang membutuhkan hubungan antar personal. Sebagai contoh apakah SDM-nya ramah atau menyenangkan.

3. Kriteria berdasarkan hasil, kriteria ini semakin populer dengan makin ditekanya produktivitas dan daya saing internasional. Kriteria ini berfokus pada apa yang telah dicapai atau dihasilkan ketimbang bagaimana sesuatu dicapai atau dihasilkan.

Faktor-Faktor yang mepengaruhi kinerja menurut Steers (dalam Suharto \& 
Cahyono 2005) faktor-faktor yang mempengaruhi kinerja adalah: (1) kemampuan, kepribadian dan minat kerja; (2) kejelasan dan penerimaan atau kejelasan peran seseorang pekerja yang merupakan taraf pengertian dan penerimaan seseorang atas tugas yang diberikan kepadanya; (3) tingkat motivasi pekerja yaitu daya energi yang mendorong, mengarahkan dan mempertahankan perilaku.

Menurut McCormick dan Tiffin (dalam Suharto \& Cahyono, 2005) menjelakan bahwa terdapat dua variabel yang mempengaruhi kinerja yaitu variabel individu yang terdiri dari pengalaman, pendidikan, jenis kelamin, umur, motivasi, keadaan fisik, kepribadian. dan variabel situasional yang menyangkut dua faktor yaitu, 1) faktor sosial dan organisasi, meliputi: kebijakan, jenis latihan dan pengalaman, sistem upah serta lingkungan sosial. 2) faktor fisik dan pekerjaan, meliputi: metode kerja, pengaturan dan kondisi, perlengkapan kerja, pengaturan ruang kerja, kebisingan, penyinaran dan temperatur.

\section{Indikator-Indikator Kinerja}

Menurut Moeheriono (dalam Abdullah, 2014:151), terdapat enam indikator kinerja namun masing-masing organisasi dapat saja mengembangkannya sesuai organisasi tersebut. Keenam kategori tersebut antara lain:

a. Kualitas: Tingkat dimana hasil aktifitas yang dilakukan mendekati sempurna dalam arti menyesuaikan beberapa cara ideal dari penampilan aktivitas ataupun memenuhi tujuan yang diharapkan dari suatu aktivitas.

b. Kuantitas: Jumlah yang dihasilkan dalam istilah jumlah unit, jumlah siklus aktifitas yang diselesaikan.

c. Ketepatan Waktu: Tingkat suatu aktifitas diselesaikan pada waktu awal yang diinginkan, dilihat dari sudut koordinasi dengan hasil output serta memaksimalkan waktu yang tersedia untuk aktifitas lain.

d. Efektifitas: Tingkat penggunaan sumber daya manusia, organisasi dimaksimalkan dengan maksud menaikan keuntungan atau mengurangi kerugian dari setiap unit dalam penggunaan sumber daya.

e. Kemandirian: Tingkat dimana seorang pegawai dapat melakukan fungsi kerjanya tanpa minta bantuan bimbingan dari pengawas atau meminta turut campurnya pengawas untuk menghindari hasil yang merugikan.

f. Komitmen Organisasi: Tingkat dimana pegawai mempunyai komitmen kerja dengan organisasi dan tanggung jawab pegawai terhadap organisasi.

\section{PENGARUH KOMUNIKASI INTERNAL TERHADAP KINERJA KARYAWAN}

Suatu perusahaan dituntut untuk memaksimalkan kinerjanya dalam bekerjasama dengan orang lain untuk berbagai keperluan seperti keperluan bisnis, profesi, sosial dan berbagai macam keperluan lainnya. Mereka bekerjasama menentukan tujuan yang ingin dicapai menyusun rencana kerja, mengelola dan menjalankan operasi bisnis organisasinya. Untuk mewujudkan itu semua, maka diperlukan suatu kebersamaan dari anggotanya, yaitu pihak internal di dalam perusahaan, apabila pihak-pihak internal didalam perusahaan itu memiliki kerjasama yang baik, kompak, dan mengutamakan kepentingan perusahaan, maka hal ini menciptakan suatu iklim kerja yang konduksif dalam perusahaan dan sudah tentu kinerja perusahaan tersebut akan menjadi lebih baik pula. 


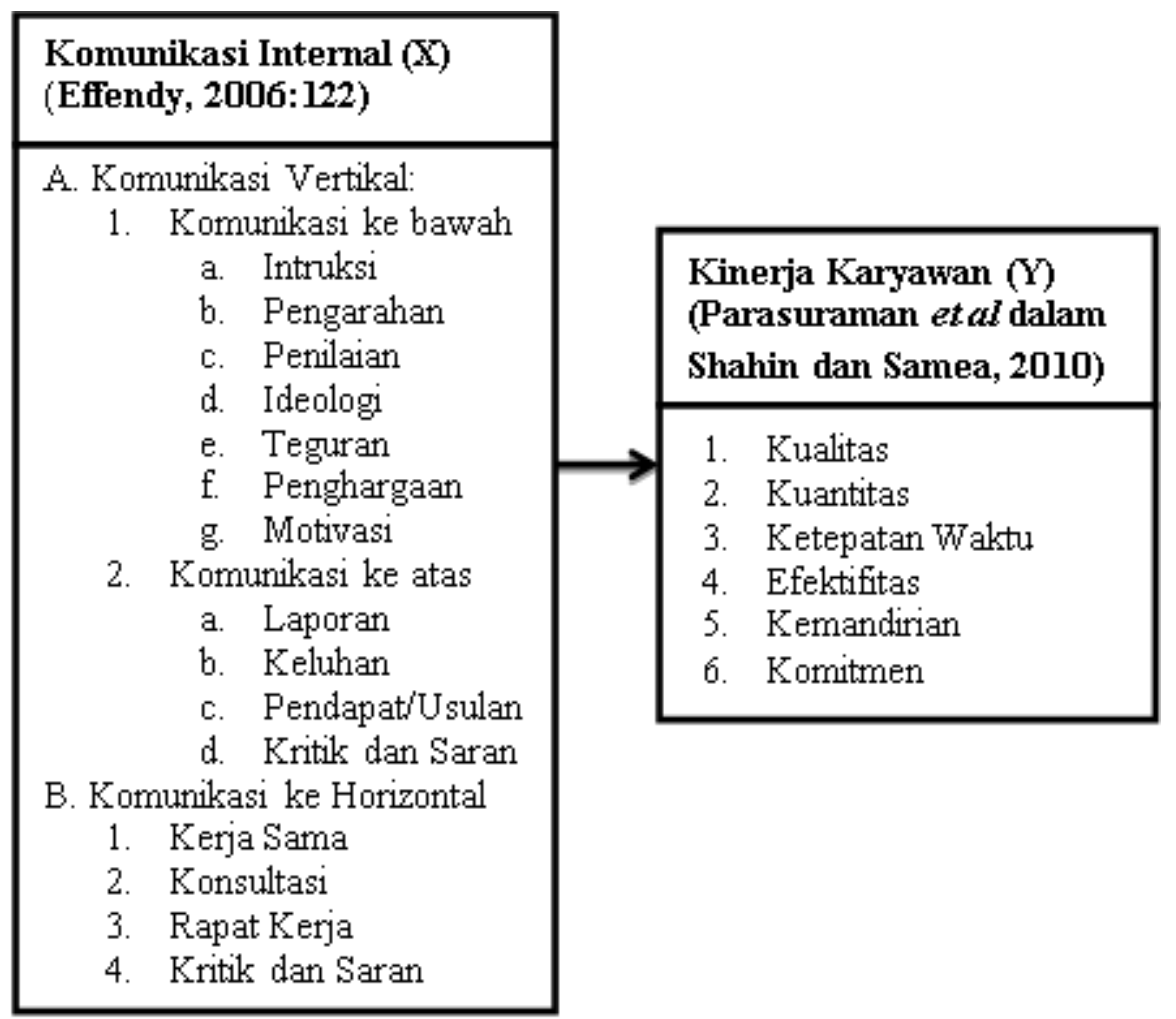

\section{Gambar 1 Gambar Model Kerangka Pikir}

\section{Kerangka Pemikiran}

Komunikasi memiliki peran yang luar biasa dalam mendukung perkembangan sebuah organisasi. Komunikasi organi-sasi sendiri terdiri dari komunikasi internal dan eksternal. Komunikasi internal masih dibagi lagi menjadi dua, yaitu formal dan informal. Pada penelitian ini akan dibahas tentang komunikasi internal yang bersifat formal yang terdiri dari komunikasi vertikal dan horizontal. Komunikasi vertikal terdiri dari komunikasi kebawah dan komunikasi ke atas. Dalam rancangan kerangka berpikir, juga dijelaskan tentang keefektifan kerja yang menjadi sumber rumusan permasalahan.

\section{Hipotesis}

Hipotesis merupakan jawaban sementara terhadap rumusan masalah penelitian. Maka dari uraian masalah yang ada, dapat dimunculkan suatu hipotesis penelitian sebagai berikut : (1) H0 : Tidak ada hubungan yang positif antara komunikasi internal organisasi dengan kinerja karyawan PT Promedrahardjo
Farmasi Industri. (2) H1: Ada hubungan yang positif antara komunikasi internal organisasi dengan kinerja karyawan PT Promedrahardjo Farmasi Industri.

\section{METODE PENELITIAN}

Jenis Dan Rancangan Penelitian Jenis metode yang dipakai peneliti dalam melakukan penelitian yaitu jenis penelitian deskriptif kuantitatif. Desain rancangan penelitian dalam penelitian ini dijelaskan pada Gambar 1.

\section{Jenis Dan Sumber Data}

Dalam penelitian ini menggunakan sumber data primer dan sekunder. data primer bersumber dari penyebaran kuesioner secara langsung kepada para responden di PT Promedrahardjo Farmasi Industri, sedangkan, data sekunder bersumber dari studi pustaka, data yang PT Promedrahardjo Farmasi Industri melalui berbagai jurnal, maupun artikel yang diambil dari internet. 
Teknik Pengumpulan Data

Teknik pengumpulan data dalam penelitian menggunakan angket dan dokumentasi dari beberapa sumber, seperti internet dan hasil olah data menggunakan SPSS 20.

\section{Uji Validitas}

Menurut Sugiyono (2014:363), "Validitas merupakan derajad ketepatan antara data yang terjadi pada obyek penelitian dengan data yang dilaporkan oleh peneliti". Nilai kritis (r-tabel) yang diperoleh sebesar 0,444 yaitu dengan melihat pada r-tabel pada signifikansi 0,05 dengan uji 2 sisi dan jumlah data $(n)=20$ diluar dari jumlah sampel yang diujikan. Dari hasil uji validitas diperoleh r-hitung dalam instrumen penelitian yang digunakan semuanya mempunyai nilai yang lebih besar atau berada di atas nilai kritis (r-tabel), sehingga dapat disimpulkan bahwa semua instrumen penelitian sudah valid.

\section{Uji Reliabilitas}

Menurut Juliansyah Noor (2012 : 131),"Realibilitas adalah indeks yang menunjukkan sejauh mana suatu alat pengukur dapat dipercaya atau dapat diandalkan". Reliabilitas suatu konstruk variabel dikatakan baik jika memiliki nilai cronbach's Alpha $>$ dari 0,60 (Nugroho, 2005:72). Nilai koefisian reliabilitas kesemua item instrumen tersebut lebih dari atau di atas 0,60, maka dapat disimpulkan bahwa semua item instrument atau angket yang digunakan sudah reliabel.

\section{Analisis Deskriptif}

Metode analisis deskriptif adalah analisis yang menggambarkan suatu data yang akan dibuat sendiri maupun secara berkelompok. Hasil data deskriptif yaitu akan diperoleh nilai maksimum, minimum dan mean. Setelah nilai mean diketahui, tahap selanjutnya yaitu menyesuaikan nilai mean yang diketahui dengan kategori interval kelas. Adapun rumus perhitungan kelas interval seperti yang dikemukakan Sudjana (2002) adalah sebagai berikut:

\begin{tabular}{|c|c|}
\hline Internal & $=\frac{\text { Nilai tertinggi-Nilai terendah }}{\text { Banyaknya kelas }}$ \\
\hline Interval & $=\frac{4-1}{4}=0.75$ \\
\hline
\end{tabular}

\section{Analisis Regresi}

Regresi sederhana adalah regresi dua variabel yang menggambarkan hubungan garis lurus antara satu variabel independen dengan satu variabel dependen.

\section{Uji Asumsi Klasik}

Gurajati (2003:59) menyatakan bahwa uji asumsi klasik adalah persyaratan statidtk yang harus dipenuhi pada analisis regresi linier. Uji asumsi klasik yang biasa digunakan adalah uji multikolinieritas, uji heteroskedastisitas, uji normalitas, uji autokorelasi dan uji linieritas. Uji asumsi klasik yang akan digunakan pada penelitian ini adalah uji normalitas, uji heteroskedastisitas dan uji linieritas.

\section{HASIL DAN PEMBAHASAN Karakteristik Responden}

Berdasarkan jenis kelamin responden didominasi oleh responden yang berjenis kelamin perempuan dari dengan jumlah sebesar 61 orang atau $61 \%$ dari keleluruhan responden. Sedangkan responden yang berjenis kelamin laki-laki berjumlah sekitar 39 orang atau 39\% dari keseluruhan responden.

Berdasarkan lama bekerja menunjukan didominasi oleh responden yang sudah bekerja selama 2-5 tahun sebanyak 43 orang atau $43 \%$, dari keseluruhan responden. Sedangkan jumlah responden terendah sebesar 20 orang atau $20 \%$ pada status lama berkerja $>5$ tahun. Hal ini menunjukkan bahwa responden paling banyak ialah responden yang 
memiliki pengalaman bekerja selama $2-4$ tahun.

\section{Analisis Dimensi Komunikasi dari Atas ke Bawah}

Melihat hasil dari penelitian yang dilakukan pada di PT Promedrahardjo Farmasi Industri indikator Instruksi mempunyai nilai tertinggi hal ini sesuai seperti yang diungkapkan oleh Katz \& Kahn, 1966 salah satunya ialah komunikasi dari atas kebawah dilakukan untuk memberitahukan bagaimana melakukan suatu pekerjaan. Dalam iklim kerja, instruksi merupakan hal yang sering dilakukan dalam konteks komunikasi dari atasan kepada bawahan. Instruksi ini dapat dilaksanakan baik secara lisan atau tertulis. Perintah atau instruksi kerja dapat berupa pemberian pengajaran sesuatu yang baru atau menyebarluaskan pada para karyawan bagaimana melakukan suatu tugas khusus.

Tabel 1 Analisis Deskriptif Dimensi Komunikasi dari Atas ke Bawah

\begin{tabular}{|l|r|r|r|c|}
\hline & Min & Max & Mean & SD \\
\hline Instruksi & 2 & 5 & 3,95 & 0,82 \\
\hline Pengarahan & 3 & 5 & 3,81 & 0,69 \\
\hline Penilaian & 2 & 5 & 3,68 & 0,73 \\
\hline Ideologi & 3 & 5 & 3,85 & 0,69 \\
\hline Teguran & 2 & 5 & 3,49 & 0,66 \\
\hline Penghargaan & 3 & 5 & 3,85 & 0,69 \\
\hline Motivasi & 2 & 5 & 3,58 & 0,69 \\
\hline $\begin{array}{l}\text { Komunikasi } \\
\text { dari atas ke } \\
\text { bawah }\end{array}$ & 3 & 5 & 3,74 & 0,50 \\
\hline
\end{tabular}

Teguran menjadi salah satu indikator terendah dibandingkan denagn indikator yang lainnya dalam hasil penelitian pada PT Promedrahardjo Farmasi Industri. Untuk keberhasilan suatu organisasi, seorang pemimpin berhak dan harus mampu memberikan teguran - teguran pada tingkatan jabatan yang lebih rendah/atau bawahan yang lalai dalam menjalankan tugas/instruksi, baik secara lisan atau tertulis (Ibid, 1966
Untuk indikator lainnya pada PT Promedrahardjo Farmasi Industri dalam dimensi komunikasi dari atas ke bawah sudah cukup baik seperti pengarahan untuk memberikan penerangan secara ringkas, penilaian untuk dasar evaluasi atau penilaian supervisor terhadap pelaksanaan kerja karyawan, penanaman ideologi ini sebagai upaya pimpinan untuk mencapaikan dan menanamkan dalam diri karyawan, sehingga akan menumbuhkan peningkatan semangat kerja, pengabdian, rasa memiliki atau dukungan terhadap organisasi, penghargaan untuk karyawan yang berprestasi, dan motivasi.

\section{Tabel 2 Analisis Deskriptif Dimensi} Komunikasi dari Bawah ke Atas

\begin{tabular}{|l|r|r|r|c|}
\hline & Min & Max & Mean & SD \\
\hline Laporan & 2 & 5 & 3,45 & 0,81 \\
\hline Keluhan & 2 & 5 & 3,68 & 0,62 \\
\hline Laporan & 1 & 5 & 3,53 & 0,81 \\
\hline $\begin{array}{l}\text { Pendapat/ } \\
\text { Usulan }\end{array}$ & 2 & 5 & 3,20 & 0,54 \\
\hline Kritik/Saran & 1 & 4 & 3,16 & 0,69 \\
\hline $\begin{array}{l}\text { Komunikasi } \\
\text { dari bawah ke } \\
\text { atas }\end{array}$ & 2 & 5 & 3,50 & 0,48 \\
\hline
\end{tabular}

\section{Analisis Dimensi Komunikasi dari Bawah ke Atas}

Pada PT Promedrahardjo Farmasi Industri melihat hasil uji penelitian yang dilakukan pada dimensi komunikasi dari bawah ke atas indikator yang paling tinggi ialah saran sama seperti yang diungkap oleh Pace dan Faules (2010) bahwa Kebanyakan analisis dan penelitian dalam komunikasi ke atas menyatakan bahwa penyelia dan manajer harus menerima informasi dari bawahan mereka yang:

a. Memberitahukan apa yang dilakukan bawahan - pekerjaan mereka, prestasi, kemajuan, dan rencana-rencana untuk waktu mendatang.

b. Menjelaskan persoalan-persoalan kerja yang belum dipecahkan bawahan yang 
mungkin memerlukan beberapa macam bantuan.

c. Memberikan saran atau gagasan untuk perbaikan dalam unit-unit mereka atau dalam organisasi sebagai suatu keseluruhan.

d. Mengungkapkan bagaimana pikiran dan perasaan bawahan tentang pekerjaan mereka, rekan kerja mereka dan organisasi.

Indikator kritik pada dari keseluruhan indikator dalam komunikasi dari bawah ke atas mempunyai nilai yang sangat baik akan tetapi lebih rendah dari pada indikator lainnya dalam dimensi ini. Hal ini bisa terjadi oleh karena beberapa sebab seperti yang diungkapkan oleh Sharma (1979) dalam Pace dan Faules (2010:184-186) dalam mengemukakan empat alasan mengapa komunikasi ke atas terlihat amat sulit.

a. Kecenderungan bagi pegawai untuk menyembunyikan pikiran mereka. Penelitian menunjukkan bahwa pegawai merasa bahwa mereka akan mendapat kesulitan bila mereka berbicara dengan penyelia mereka dan cara yang terbaik untuk naik pangkat dalam organisasi tersebut adalah sepakat dengan penyelia mereka.

b. Perasaan bahwa penyelia dan manajer tidak tertarik kepada masalah pegawai. Pegawai sering kali melaporkan bahwa manajer mereka tidak memperhatikan masalah mereka. Manajer mungkin tidak memberi tanggapan terhadap masalah pegawai dan mungkin menahan beberapa komunikasi ke atas karena hal itu mungkin membuat mereka terlibat buruk dalam pandangan atasan mereka.

c. Kurangnya penghargaan bagi komunikasi ke atas yang dilakukan pegawai. Seringkali penyelia dan manajer tidak berhasil memberi penghargaan yang nyata atau terselubung untuk mempertahankan agar saluran komunikasi ke atas tetap terbuka. d. Perasaan bahwa penyelia dan manajer tidak dapat dihubungi dan tidak tanggap pada apa yang disampaikan pegawai. Bisa terjadi penyelia terlalu sibuk untuk mendengarkan atau bawahan tidak dapat menemukan mereka. Bila penyelia ada di tempatnya, ia tidak tanggap pada apa yang dikatakan bawahan tersebut.

\section{Analisis Dimensi Komunikasi Horizontal}

Komunikasi horizontal terdiri dari penyampaian informasi diantara rekanrekan sejawat dalam unit kerja yang sama. Unit kerja meliputi individu-individu yang ditempatkan pada tingkat otoritas yang sama dalam organisasi dan mempunyai atasan yang sama, diungkapkan oleh Sharma (1979) dalam Pace dan Faules (2010:184-186).

\section{Tabel 3 Analisis Deskriptif Dimensi Komunikasi Horizontal}

\begin{tabular}{|l|r|r|r|c|}
\hline & \multicolumn{1}{|c|}{ Min } & Max & Mean & SD \\
\hline Rapat & 3 & 5 & 3,81 &, 694 \\
\hline Kerjasama & 2 & 5 & 3,68 &, 739 \\
\hline Konsultasi & 3 & 5 & 3,85 &, 690 \\
\hline $\begin{array}{l}\text { Komunikasi } \\
\text { Horizontal }\end{array}$ & 3 & 5 & 3,78 &, 576 \\
\hline
\end{tabular}

Pada PT Promedrahardjo Farmasi Industri melihat hasil uji penelitian yang dilakukan pada dimensi Komunikasi Horizontal indikator yang paling tinggi ialah konsultasi.

\section{Analisis Kinerja Karyawan}

Pada PT Promedrahardjo Farmasi Industri kualitas dan kuantitas mempunyai nilah terendah yaitu 2,48 dimana menurut Menurut Moeheriono (dalam Abdullah, 2014:151) kualitas merupakan tingkat dimana hasil aktifitas yang dilakukan mendekati sempurna dalam arti menyesuaikan beberapa cara ideal dari penampilan aktivitas ataupun memenuhi tujuan yang diharapkan dari suatu 
aktivitas dan kuantitas: Jumlah yang dihasilkan dalam istilah jumlah unit, jumlah siklus aktifitas yang diselesaikan hal ini mempunyai nilai rendah bisa saja karena komunikasi internal bukanlah salah satu variabel utama yang mempengaruhi kinerja karyawan di perusahaan tersebut tetapi adanya faktor lain yang tidak diteliti dalam penelitian ini.

\section{Tabel 4 Analisis Deskriptif Kinerja Karyawan}

\begin{tabular}{|l|r|r|r|c|}
\hline & Min & Max & Mean & SD \\
\hline Kemandirian & 3 & 5 & 4,26 & 0,51 \\
\hline Kuantitas & 1 & 5 & 2,48 & 1,09 \\
\hline $\begin{array}{l}\text { Ketepatan } \\
\text { waktu }\end{array}$ & 3 & 5 & 4,26 & 0,51 \\
\hline Komitmen & 1 & 5 & 3,99 & 0,82 \\
\hline $\begin{array}{l}\text { Ketepatan } \\
\text { waktu }\end{array}$ & 1 & 5 & 2,48 & 1,09 \\
\hline Kemandirian & 3 & 5 & 4,26 & 0,51 \\
\hline Kualitas & 1 & 5 & 3,99 & 0,82 \\
\hline Efektitifitas & 1 & 5 & 3,99 & 0,82 \\
\hline Kualitas & 1 & 5 & 2,48 & 1,09 \\
\hline $\begin{array}{l}\text { Kinerja } \\
\text { Karyawan }\end{array}$ & 2 & 5 & 3,58 & 0,58 \\
\hline
\end{tabular}

Pada PT Promedrahardjo Farmasi Industri, kemandirian merupakan salah satu indikator dengan nilai paling tinggi dalam dimensi kinerja karyawan ini. Kemandirian merupakan tingkat dimana seorang pegawai dapat melakukan fungsi kerjanya tanpa minta bantuan bimbingan dari pengawas atau meminta turut campurnya pengawas untuk menghindari hasil yang merugikan.

\section{Pengaruh Komunikasi Internal terhadap Kinerja Karyawan}

Berdasarkan hasil dari analisis regresi didapatkan konstanta (a) bernilai 22,148 dengan koefisien regresi (b) sebesar 0,171. Dengan begitu, maka dapat diketahu bahwa persamaan regresi yang diperoleh penelitian ini adalah:

$$
\begin{aligned}
& Y=a+b X \\
& Y=22,148+0,250 X
\end{aligned}
$$

Melalui persamaan tersebut, dapat diintepretasikan bahwa jika komunikasi internal bernilai nol $(X=0)$, maka nilai kinerja karyawan sebesar 22,148. Selain itu, jika terjadi penambahan/peningkatan pada komunikasi internal sebesar satu satuan, maka kinerja karyawan akan mengalami peningkatan sebesar 0,250 satuan. Hal ini menunjukan bahwa komunikasi internal berpengaruh positif terhadap kinerja karyawan atau peningkatan komunikasi internal akan diikuti dengan peningkatan kinerja karyawan.

Nilai koefisen determinasi ( $\mathrm{R}$ Square/R2) dari komunikasi internal terhadap kinerja karyawan adalah sebesar 0,062. Dengan begitu, maka dapat diketahui bahwa hasil perhitungan koefisien determinasi pada penelitian ini adalah:

$$
\begin{aligned}
& \mathrm{KD}=\left(\mathrm{r}^{2}\right) \times 100 \% \\
& \mathrm{KD}=(0,062) \times 100 \% \\
& \mathrm{KD}=6,2 \%
\end{aligned}
$$

Hal ini menunjukkan bahwa komunikasi intrenal memberikan kontribusi pengaruh sebesar 6,2\% terhadap kinerja karyawan. Sedangkan sisanya 93,8 $\%$ merupakan kontribusi variabel lain yang tidak diteliti dalam penelitian ini. FaktorFaktor lain yang mepengaruhi kinerja menurut Steers (dalam Suharto \& Cahyono 2005) adalah:

1. Kemampuan, kepribadian dan minat kerja.

2. Kejelasan dan penerimaan atau kejelasan peran seseorang pekerja yang merupakan taraf pengertian dan penerimaan seseorang atas tugas yang diberikan kepadanya.

3. Tingkat motivasi pekerja yaitu daya energi yang mendorong, mengarahkan dan mempertahankan perilaku.

Untuk meningkatkan terjalinnya suatu hubungan sosial yang baik antara bawahan dengan pimpinan perusahaan, perlu adanya kebebasan berkomunikasi supaya lebih efektif memberikan solusi dan atasan memberikan teguran apabila 
karyawan tidak dapat melaksanakan tugasnya dengan benar dan memberikan reward yang sesuai apabila karyawan dapat melaksanakan tugasnya dengan benar dan berprestasi.

Untuk meningkatkan persoalan mengenai mengemukakan pendapat atau inisiatif apabila ada permasalahan dalam perusahaan, bahwa saran atau kritik dari karyawan harus didengarkan dan dihargai, bahkan di jadikan bahan pertimbangan dalam pengambilan keputusan.

Untuk meningkatkan kerjasama antar pegawai bisa dilakukan dengan cara dengan melaksanakan kegiatan bersama yang membuat antar karyawan menjadi lebih mengenal dan saling tebuka misal mengadakan acara gathering besama.

\section{KESIMPULAN DAN SARAN Kesimpulan}

1. Pelaksanaan komunikasi internal pada PT Promedrahardjo Farmasi Industri sudah dilaksanakan dengan baik. Hal tersebut dapat dilihat nilai rata-rata keseluruhan tentang pelaksanaan komunikasi internal dalam PT Promedrahardjo Farmasi Industri seperti komunikasi dari atas ke bawah, nilai dari komunikasi bawah ke atas dan nilai komunikasi horizontaltermasuk dalam kategori baik. Namun demikian dalam hal terjalinnya suatu hubungan sosial yang baik antara bawahan dengan pimpinan perusahaan dinilai kurang, karena memiliki nilai rata-rata terendah.

2. Kinerja karyawan PT Promedrahardjo Farmasi Industri dinilai sudah baik. Namun demikian dalam hal bertanggung jawab terhadap pekerjaan yang menjadi tugasnya, mampu menggerakkan bawahan untuk bekerja secara efektif, dan mengemukakan pendapat atau inisiatif apabila ada permasalahan dalam perusahaan dinilai kurang, karena memiliki nilai rata-rata terendah.
3. Hasil penelitian menunjukkan bahwa komunikasi internal telah baik namun belum sepenuhnya maksimal. Hal tersebut terlihat pada tanggapan responden pada beberapa indikator pertanyaan yang masih memilih menjawab kurang. Dari kesimpulan yang dapat diambil dari indikator komunikasi internal organisasi dan berdasarkan wawancara pada sebagian responden yang menjawab dengan nilai skor rendah, menyatakan bahwa hal tersebut dikarenakan pribadi dari masing- masing karyawan, merasa kurang mampu untuk bekerjasama dengan baik pada rekan kerjanya.

\section{Saran}

1. Untuk meningkatkan terjalinnya suatu hubungan sosial yang baik antara bawahan dengan pimpinan perusahaan, perlu adanya kebebasan berkomunikasi supaya lebih efektif memberikan solusi.

2. Untuk mengatasi permasalahan mengenai bertanggung jawab terhadap pekerjaan yang menjadi tugasnya, pihak perusahaan diharuskan memberikan sanksi yang tegas apabila karyawan tidak dapat melaksanakan tugasnya dengan benar dan memberikan reward yang sesuai apabila karyawan dapat melaksanakan tugasnya dengan benar dan berprestasi.

3. Untuk mengatasi permasalahan mengenai mengemukakan pendapat atau inisiatif apabila ada permasalahan dalam perusahaan, bahwa saran atau kritik dari karyawan harus didengarkan dan dihargai, bahkan di jadikan bahan pertimbangan dalam pengambilan keputusan.

4. Untuk meningkatkan kerjasama antar pegawai bisa dilakukan dengan cara dengan melaksanakan kegiatan bersama yang membuat antar karyawan menjadi lebih mengenal dan saling tebuka misal mengadakan acara gathering besama. 
5. Untuk penelitian lain diharapkan untuk menggunakan variabel-variabel lain selain komunikasi internal untuk menguji faktor terhadap kinerja kartawan dikarenakan pengaruh dari komunikasi intenal terhadap kinerja karyawan kecil.

\section{DAFTAR PUSTAKA}

Abdullah, M. (2014). Manajemen dan Evaluasi Kinerja Karyawan. Yogyakarta: Aswaja Pressindo.

Aguerrebere, P. M. (2015). Management of the Internal Communication in Hospitals: Conceptual Framework and Implementation Model. Journal International University of Catalonia Spain, 54-65.

Argenti, P. A. (2010). Komunikasi Korporat. Jakarta: Salemba Humanika.

Cahyono, B., \& Suharto. (2005). Pengaruh Budaya Organisasi, Kepemimpinan dan Motivasi Kerja Terhadap Kinerja Sumber Daya Manusia di Sekretariat DPRD Propinsi Jawa Tengah. JRBI Yogyakarta Vol. 1.

Didier, N. (2011). Pengaruh Komunikasi Internal Terhadap Kepuasan Kerja dalam Sebuah Organisasi: Studi Kasus PT. XYZ. Jurnal Humaniora Vol. 2 No. 1.

Effendy, O. U. (2001). Ilmu Komunikasi Teori dan Praktek. Bandung: PT. Remaja Rosdakarya.

Effendy, O. U. (2006). Ilmu Komunikasi; Teori dan Praktek. Bandung: Remaja Rosda Karya.

Ghozali, I. (2011). Aplikasi Analisis Multivariate Dengan Program SPSS. Semarang: Badan Penerbit Universitas Diponegoro.

Hikayat, B. (2010). Pengaruh Komunikasi Internal Terhadap Prestasi Kerja Karyawan pada PT Millenium Penata Futures Bandung. Bandung: Universitas Widyatama.

Moore, D. (1998). Fungal Morphogenesis 1st Ed. United Kingdom: Cambridge University Press.
Mulyana. (2000). Ilmu Komunikasi Suatu Pengantar. Bandung: PT Remaja Rosda Karya.

Pace R., W., \& F., F. D. (2010). Komunikasi Organisasi: Strategi Meningkatkan Kinerja Perusahaan. Bandung: PT. Remaja Rosdakarya.

Pace R., W., \& Faules, D. F. (2006). Komunikasi Organisasi: Strategi meningkatkan kinerja perusahaan (Editor Deddy Mulyana, MA., Ph.D.). Bandung: PT. Remaja Rosdakarya.

Riniwati, H. (2011). Mendongkrak Motivasi dan Kinerja: Pendekatan Pemberdayaan SDM. Malang: UB Press.

Sudjana, \& Ibrahim. (2007). Penelitian dan Penilaian Pendidikan. Bandung: Sinar Baru Algesindo.

Sugiyono. (2006). Metode Penelitian Bisnis. Bandung: Alfabeta.

Sugiyono. (2007). Metode Penelitian Kuantitatif Kualitatif dan $R \& D$. Bandung: Alfabeta.

Sugiyono. (2009). Metode Penelitian Bisnis. Bandung: Alfabeta.

Sugiyono. (2014). Metode Penelitian Kuantitatif, Kualitatif dan Kombinasi (Mixed Methods). Bandung: Alfabeta.

Sukmadinata, N. S. (2013). Metode Penelitian Pendidikan Bandung. Bandung: PT. Remaja Rosdakarya.

Wirartha, I. M. (2006). Metodologi Penelitian Sosial Ekonomi. Yogyakarta: CV. Andi Offset.

Zondi, S. (2015). Internal Communication Challenges and Issues: A Case Study of Transnet Freight Rail Business Unit Coal. Journal of Business and Management Review, Vol. 4, 105-145. 